\title{
29. CRETACEOUS AND PALEOGENE COCCOLITH STRATIGRAPHY, DEEP SEA DRILLING PROJECT, LEG 26'
}

\author{
David Bukry, United States Geological Survey, La Jolla, California
}

\section{INTRODUCTION}

Drilling on Leg 26 of the Deep Sea Drilling Project, Sept. to Oct. 1972, through the southern Indian Ocean from Durban, South Africa, to Fremantle, Australia (Figure 1), recovered 239 cores at nine drilling sites, Sites 250-258. Light-microscope techniques were used to study the Cretaceous and Paleogene coccoliths of 99 samples from these cores. Cretaceous coccolith zonation is based primarily on Thierstein (1971) and Roth (1973) with supporting data from Cepek and Hay (1969) and Manivit (1971). Paleogene coccolith zonation is based on Bukry (in press).

\section{SITE SUMMARIES}

\section{SITE 250}

(lat $33^{\circ} 27.74^{\prime} \mathrm{S}$, long $39^{\circ} 22.15^{\prime} \mathrm{E}$, depth $5119 \mathrm{~m}$ )

Coccoliths occur in only 3 of the 13 samples examined from Site 250, which was cored to determine the basement age in the southeastern Mozambique Basin. This region is devoid of prominent magnetic anomalies. The coccoliths are Late Cretaceous (Santonian) in age (Figure 2) and are present in sediment 10 to 20 meters above basement. All assemblages are strongly etched and are dominated by a few solution-resistant species. In Core 22A (691-701 mे), Marthasterites furcatus and

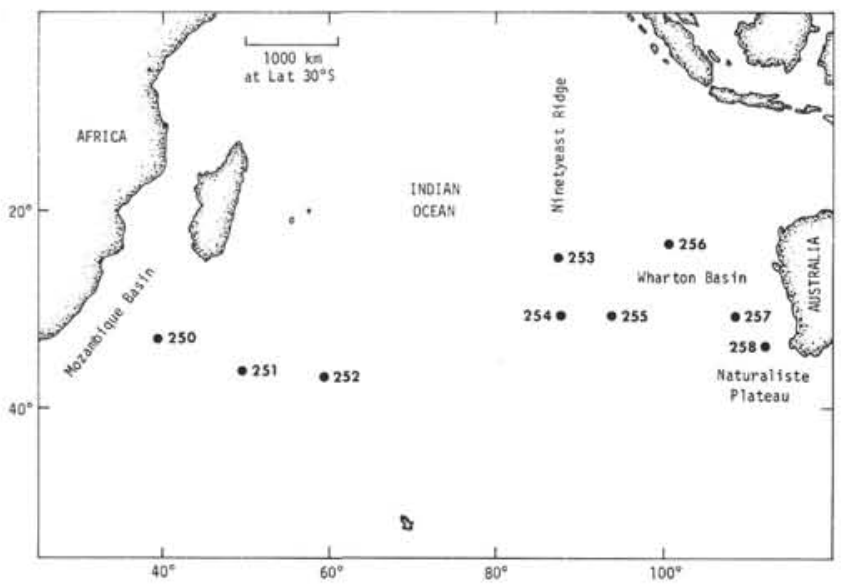

Figure 1. Location of Deep Sea Drilling Project Leg 26 drilling sites.

'Publication authorized by the Director, U.S. Geological Survey.

\begin{tabular}{l|c|c|c}
\hline $\begin{array}{c}\text { Sample } \\
\text { (Interval in cm) }\end{array}$ & $\begin{array}{c}\text { Quantity } \\
\text { and } \\
\text { Preservation }\end{array}$ & Zone & Stage \\
\hline $18 \mathrm{~A}-2,80$ & - & & \\
$19 \mathrm{~A}-2,78$ & - & & \\
$20 \mathrm{~A}-1,66$ & - & & \\
$20 \mathrm{~A}-2,62-63$ & - & & \\
$21 \mathrm{~A}-2,108$ & - & & \\
$22 \mathrm{~A}-1,90$ & - & & \\
$22 \mathrm{~A}-2,92$ & - & & \\
$22 \mathrm{~A}-3,37$ & $\mathrm{Cp}(-3.5)$ & & \\
$22 \mathrm{~A}-4,3$ & $\mathrm{Rp}(-4.0)$ & Marthasterites & Santonian \\
$23 \mathrm{~A}-1,25$ & $\mathrm{Ap}(-3.0)$ & furcatus & \\
$23 \mathrm{~A}-2,18$ & - & $?$ & $?$ \\
$24 \mathrm{~A}-1,97$ & - & $?$ & $?$ \\
$24 \mathrm{~A}-2,30$ & - & & \\
$25 \mathrm{~A}-1,16$ & - & & \\
\hline
\end{tabular}

Figure 2. Quantity, preservation, zone, and stage designations of samples from Hole $250 \mathrm{~A}$ based on coccoliths. Quantity indicated as A, abundant; C, common; R, rare; or -, absent. Poor preservation throughout indicated by $\mathrm{p}$ and further refined by numerical preservation code in which $-4.0=$ almost all specimens fragmented by etching, and $-3.0=$ many major structures removed by etching (Bukry, 1973).

Micula decussata predominate, whereas in Core 23A (701-711 m), Watznaueria barnesae and Micula decussata predominate.

An age of $83 \pm 6$ m.y. is assigned to these assemblages. This age is derived by the error-estimate technique of van Andel and Bukry (1973) using the age indicated for the Mesozoic coccolith zone (Figure 3). As noted by Lambert (1971) and by Douglas and Bukry (1973), the age determinations of Mesozoic stage boundaries are interpolations of sparse and often poorly correlated radiometric data. Below the Cenomanian stage much of the radiometric data are based on determinations from glauconite and cannot be considered highly accurate. The ages of zone boundaries, within the stages, are then further extrapolations. Until more radiometric determinations are available, such extrapolated ages should be viewed only as the best current estimates. The relative ages between zones may be improved more rapidly of drilling of Mesozoic magnetic anomaly sequences in the ocean basins is successful.

SITE 251

(lat $36^{\circ} 30.26^{\prime} \mathrm{S}$, long $4^{\circ} 29.08^{\prime} \mathrm{E}$, depth $3489 \mathrm{~m}$ )

No Cretaceous or Paleogene sediment was recovered at this site. 


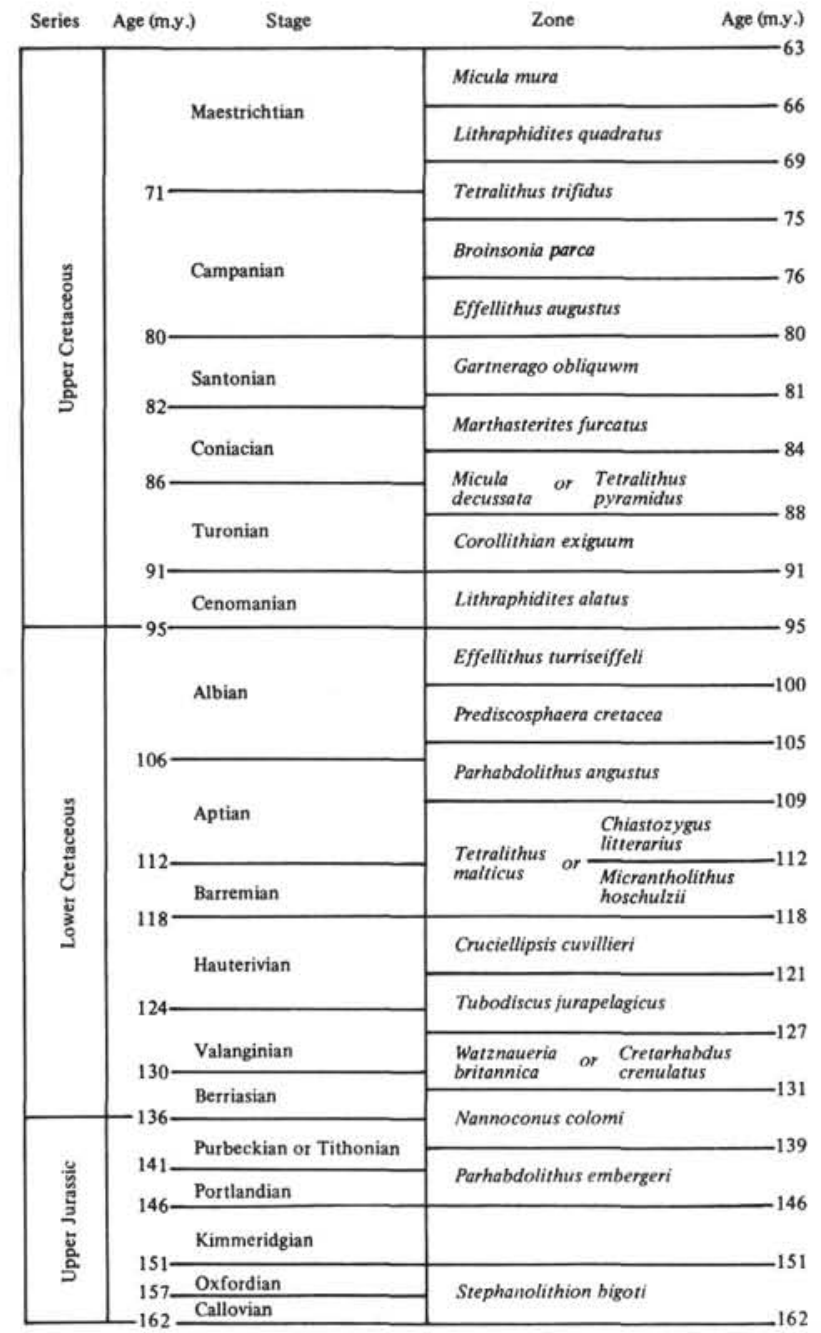

Figure 3. Estimated ages of Mesozoic coccolith zone and universal stage boundaries. Ages in m.y. obtained from the Phanerozoic Time Scale of Harland et al. (1964), Lambert (1971), and Izett et al. (1971). Coccolith zonation based on Stradner (1964), Cepek and Hay (1969), Thierstein (1971), Bukry (in press), and Roth (1973).

\section{SITE 252}

(lat $37^{\circ} 02.44^{\prime} \mathrm{S}$, long $59^{\circ} 14.33^{\prime} \mathrm{E}$, depth $5032 \mathrm{~m}$ )

No Cretaceous or Paleogene sediment was recovered at this site.

\section{SITE 253}

(lat $24^{\circ} 52.65^{\prime} \mathrm{S}$, long $87^{\circ} 21.97$ ' , depth $1962 \mathrm{~m}$ )

Of the 57 cores cut at Site 253 on the Ninetyeast Ridge, 44 are assigned to the Eocene on the basis of coccoliths (Figure 4). Unfortunately, extensive solution of coccoliths (preservation -3 to -5 ) and dilution in rapidly accumulated volcanic ash make most of the lower section, in Cores 17 to $57(152-555 \mathrm{~m})$, useless as a biostratigraphic reference. The age range of the rare cosmopolitan coccoliths in the lowest sample, 253-57-3, $115-116 \mathrm{~cm}(548 \mathrm{~m})$, yields an estimated age of $50 \pm 3$ m.y.

\begin{tabular}{|c|c|c|c|}
\hline $\begin{array}{c}\text { Sample } \\
\text { (Interval in cm) }\end{array}$ & $\begin{array}{l}\text { Quantity } \\
\text { and } \\
\text { Preservation }\end{array}$ & Zone or Subzone & Subseries \\
\hline \multirow{2}{*}{$\begin{array}{l}12-3,59-60 \\
13-1,80-81\end{array}$} & \multirow{2}{*}{$\begin{array}{l}\text { Ap } \\
\text { Am }\end{array}$} & Reticulofenestra hillae & \multirow{3}{*}{$\begin{array}{c}\text { Lower } \\
\text { Oligocene }\end{array}$} \\
\hline & & & \\
\hline & $\begin{array}{l}\text { Am } \\
\mathrm{Am}\end{array}$ & Cyclococcolithina formosa & \\
\hline $\begin{array}{l}14-1,80-81 \\
14-3,75-77\end{array}$ & \multirow{2}{*}{$\begin{array}{l}\text { Am } \\
\text { Am }\end{array}$} & Discoaster barbadiensis & \multirow{2}{*}{$\begin{array}{c}\text { Upper } \\
\text { Eocene }\end{array}$} \\
\hline $\begin{array}{l}14-3,75-77 \\
16-4,141-142\end{array}$ & & Discoaster saipanensis & \\
\hline $17-3,31-32$ & - & $?$ & \multirow{5}{*}{$\begin{array}{l}\text { Middle } \\
\text { Eocene }\end{array}$} \\
\hline $18-2,80-81$ & $\mathrm{Cm}$ & \multirow{4}{*}{ Rhabdosphaera inflata } & \\
\hline $19-2,28-29$ & Rp & & \\
\hline $20-2,80-81$ & $\mathrm{Cm}$ & & \\
\hline \multirow{2}{*}{$\begin{array}{l}21-2,85-86 \\
25-1,100-101\end{array}$} & \multirow{2}{*}{$\begin{array}{l}\mathrm{Am} \\
\mathrm{Cp}\end{array}$} & & \\
\hline & & & \multirow{5}{*}{-----} \\
\hline $30-1,94-95$ & Rp & & \\
\hline $31-3,40-41$ & $\mathrm{Cm}$ & & \\
\hline $36-2,24-25$ & - & & \\
\hline $38-1,136-137$ & Rp & & \\
\hline $40-3,66-67$ & - & & Lower \\
\hline $42-2,37-38$ & - & & Middle \\
\hline $43-2,131-132$ & Rp & & Eocene \\
\hline $46-2,113-114$ & Rp & & \\
\hline $46-6,122-123$ & Rp & ? & or \\
\hline $48-2,33-34$ & - & & \\
\hline $49-2,116-117$ & - & & Upper \\
\hline $49-3,36-37$ & - & & lower \\
\hline $51-3,108-109$ & $\mathrm{Cm}$ & & Eocene \\
\hline $51-4,122-123$ & Rp & & \\
\hline $55-2.135-136$ & $C p$ & & \\
\hline $56-1.124-125$ & $C p$ & & \\
\hline $57-3.115-116$ & $\mathrm{Rp}$ & & \\
\hline
\end{tabular}

Figure 4. Quantity, preservation, zone or subzone, and subseries designations of samples from Site 253 based on coccoliths. Quantity indicated as A, abundant; C, common; R, rare; or -, absent. Preservation indicated as g, good; $\mathrm{m}$, moderate; or $\mathrm{p}$, poor.

The best Paleogene assemblages are late middle Eocene to early Oligocene in Cores 12 to 16 (104-152 m). The early Oligocene Reticulofenestra hillae Subzone is identified in Sample 253-12-3, 59-60 cm (108 m), which contains Chiasmolithus altus, C. oamaruensis, Coccolithus eopelagicus, Cyclicargolithus floridanus, Dictyococcites bisectus, Discoaster sp. cf. D. deflandrei, D. sp. cf. D. nodifer, D. sp. cf. D. tanii, Reticulofenestra hillae, and Sphenolithus moriformis. The slightly older early Oligocene assemblages of Core 13 are distinguished by the occurrence of Cyclococcolithina formosa and Reticulofenestra umbilica. A temperate paleoenvironment is suggested by the scarcity of Sphenolithus.

Late Eocene Discoaster barbadiensis Zone assemblages occur in Core 14 and are noteworthy for the great abundance of Reticulofenestra umbilica. Sample 253-14-1, $80-81 \mathrm{~cm}$ (124 m) contains Bramletteius serraculoides, Coccolithus eopelagicus, Cyclicargolithus sp. cf. C. floridanus, Cyclococcolithina formosa, Dictyococcites scrippsae, Discoaster nodifer, D. saipanensis, D. tanii, Reticulofenestra umbilica, Sphenolithus moriformis, and Zygrhablithus bijugatus.

A late middle Eocene Discoaster saipanensis Subzone assemblage occurs in Sample 253-16-4, 141-142 cm (148 $\mathrm{m})$, which is a coccolith ooze. The ratio of Discoaster to Chiasmolithus, $82 \%$ to $18 \%$ based on a count of 300 individuals, ordinarily indicates a warm-water assemblage. In the volcanogenic-rich sediment of subjacent 
Sample $253-18-2,80-81 \mathrm{~cm}(163 \mathrm{~m})$; however, the ratio is reversed to $2 \%$ Discoaster to $98 \%$ Chiasmolithus based on a count of 300 individuals. Such an extreme ratio suggests a cool-temperate assemblage. This lower middle Eocene sample, assigned to the Rhabdosphaera inflata Subzone, is chronostratigraphically about 4 m.y. older than the overlying sample, which accounts, in part, for the apparent abruptness of the shift. Possible contributing to the effect is the evolutionary extinction of Chiasmolithus solitus just below the Discoaster saipanensis Subzone and hence between the samples. The change from coccolith-rich to volcanic-rich sediment also suggests a stratigraphic break. Coccoliths present in Sample 253-18-2, 80-81 cm include Braarudosphaera bigelowii, B. discula, Chiasmolithus expansus, C. grandis, C. solitus, Coccolithus jugatus, C. pelagicus, Cyclicargolithus pseudogammation, Discoaster barbadiensis, Ellipsolithus lajollaensis, Helicopontosphaera lophota, H. seminulum, Markalius inversus, Reticulofenestra dictyoda, Rhabdosphaera inflata s. str., $R$. tenuis, $R$. truncata, Transversopontis pulcher, T. pulcheroides, Zygolithus dubius, and Zygrhablithus bijugatus. The presence of Braarudosphaera, Ellipsolithus, Rhabdosphaera, and Transversopontis suggests fairly shallow deposition. Diatoms are common; silicoflagellates and ebridians are rare. Silicoflagellates are represented only by predominant Naviculopsis constricta and fragments of Corbisema probably derived from $C$. geometrica and $C$. triacantha. The absence of Naviculopsis foliacea and Dictyocha hexacantha suggests early middle Eocene age (Bukry and Foster, in press), particularly in view of the good preservation of $N$. constricta. The ebridians Ebriopsis crenulata and Ammodochium sp. support only a general Eocene age.

Sample 253-20-2, 80-81 cm (182 m) contains Braarudosphaera discula, Chiasmolithus expansus, $C$. grandis, C. solitus, Coccolithus jugatus, C. pelagicus, Cyclicargolithus floridanus, Cyclococcolithina formosa, Discoaster barbadiensis, Ellipsolithus lajollaensis, Helicopontosphaera lophota, Micrantholithus crenulatus, Reticulofenestra dictyoda, $R$. sp. cf. $R$. samodurovi, Transversopontis pulcher, T. pulcheroides, Zygolithus dubius, Zygrhablithus bijugatus. Downhole contamination by Neogene sediment is indicated by the presence of Cyclococcolithina macintyrei, Discoaster sp. cf. D. brouweri, and $D$. pentaradiatus.

In Sample 253-21-2, 85-86 cm (191 m), the lowest assemblage assigned to the Rhabdosphaera inflata Subzone contains $11 \%$ Discoaster and $89 \%$ Chiasmolithus in a count of 300 specimens of these genera. This temperate-water assemblage contains Braarudosphaera bigelowii, Chiasmolithus expansus, C. grandis, C. solitus, Coccolithus pelagicus, Cyclicargolithus pseudogammation, Cyclolithella bramlettei, Discoaster barbadiensis, $D$. nonaradiatus, $D$. sublodoensis, D. wemmelensis, Ellipsolithus lajollaensis, Helicopontosphaera lophota, Koczyia wechesensis, Micrantholithus crenulatus, Reticulofenestra dictyoda, Transversopontis pulcher, T. pulcheroides, Zygolithus dubius, and Zygrhablithus bijugatus.

Assemblages from deeper cores are similar but are stratigraphically less diagnostic. The Discoaster to Chiasmolithus ratio in two of the better samples is similar to that for Core 21. Sample 253-31-3, 40-41 cm (282 m) has $8 \%$ Discoaster to $92 \%$ Chiasmolithus; Sample $253-5 /-3,108-109 \mathrm{~cm}(472 \mathrm{~m}), 10 \%$ Discoaster to $90 \%$ Chiasmolithus, based on counts of 300 individuals. Micrantholithus and Braarudosphaera, suggesting a shallower depositional environment, are more common in Sample 253-31-3 than in higher samples. Coccoliths present in Sample253-31-3 include Braarudosphaera discula, Chiasmolithus grandis, C. solitus, Coccolithus pelagicus, Cyclicargolithus pseudogammation, Cyclococcolithina gammation, Discoaster barbadiensis, D. distinctus, D. sp. cf. D. mirus, D. sp. cf. D. sublodoensis, Helicopontosphaera lophota, $H$. seminulum, Micrantholithus crenulatus, Reticulofenestra dictyoda, Sphenolithus radians, and Zygolithus dubius. Sample 253-51-3 contains Chiasmolithus expansus, C. grandis, C. solitus, Coccolithus pelagicus, Cyclicargolithus pseudogammation, Discoaster barbadiensis, D. distinctus, D. lodoensis, D. sp. cf. D. mirus, Lophodolithus mochlophorus, Micrantholithus crenulatus, M. sp. cf. M. flos, $M$. sp. cf. M. attenuatus, Reticulofenestra dictyoda, Rhabdosphaera sp., Transversopontis pulcher, T. pulcheroides, Zygolithus dubius, and Zygrhablithus bijugatus.

\section{SITE 254}

(lat $30^{\circ} 58.15 ' \mathrm{~S}, 8^{\circ} 53.72 ' \mathrm{E}$, depth $1253 \mathrm{~m}$ )

No Cretaceous or Paleogene sediment was recovered at this site.

\section{SITE 255}

(lat $31^{\circ} 07.87^{\prime} \mathrm{S}$, long $93^{\circ} 43.72^{\prime} \mathrm{E}$, depth $1144 \mathrm{~m}$ )

No Cretaceous or Paleogene sediment samples were available from this site.

\section{SITE 256 \\ (lat $23^{\circ} 27.35^{\prime} \mathrm{S}$, long $100^{\circ} \mathbf{4 6 . 4 6} \mathrm{E}$, depth $5361 \mathrm{~m}$ )}

Cretaceous coccoliths occur in Cores 8 and 9 (238-257 m) from Site 256 in the Wharton Basin, west of Australia.

The assemblage is Albian in age and is similar in species composition to the Albian of Site 258 on the Naturaliste Plateau. The deepest sample available, 256-9-1, 111$112 \mathrm{~cm}(247 \mathrm{~m})$, contains the most diverse assemblage; it includes Cretarhabdus crenulatus, Cribrosphaera ehrenbergii, $C$. sp. (two-piece diagonal central-area crossbar), Cyclagelosphaera margerelii, Eiffellithus turriseiffeli, Lithastrinus floralis, Manivitella pemmatoidea, Parhabdolithus embergeri, Prediscosphaera cretacea, Watznaueria barnesae, $W$. sp. cf. $W$ bayackii, $W$. biporta, W. britannica, W. ovata, Zygodiscus bicrescenticus, $Z$. sp. cf. $Z$. deflandrei. The assemblage of Sample $256-8-1,95-96 \mathrm{~cm}(239 \mathrm{~m})$ is more etched, but differs mainly by the absence of Cribrosphaera and Cyclagelosphaera. No species suggesting Cenomanian, such as Lithraphidites alatus, Gartnerago obliquum, or Eiffellithus augustus, were observed from this site (Figure 5).

\section{SITE 257}

(lat $30^{\circ} 59.16^{\prime} \mathrm{S}$, long $108^{\circ} 20.99^{\prime} \mathrm{E}$, depth $5278 \mathrm{~m}$ )

Coccoliths of Early Cretaceous (Albian) age occur in four of the eight samples examined from Site 257 in the southeastern Wharton Basin near the Naturaliste 


\begin{tabular}{l|c|c|c}
\hline $\begin{array}{c}\text { Sample } \\
\text { (Interval in cm) }\end{array}$ & $\begin{array}{c}\text { Quantity } \\
\text { and } \\
\text { Preservation }\end{array}$ & Zone & Stage \\
\hline $1-2,99-100$ & - & $?$ & $?$ \\
$6-4,93-94$ & - & - & Albian \\
$7-3,85-86$ & Ap & Eiffellithus & Als \\
$8-1,95-96$ & Am & turriseiffeli & \\
$8-3,90-91$ & Am & & \\
$9-6,81-82$ & & & \\
\hline
\end{tabular}

Figure 5. Quantity, preservation, zone, and stage designations of samples from Site 256 based on coccoliths. See Figure 4 for key to abbreviations.

Plateau. The diagnostic fossil for the zonal assignment Prediscosphaera cretacea is rare, but is present in the highest and lowest coccolith samples (Figure 6). The lower sample, 257-8-2, 3-4 cm (239 m), is most diverse, containing Biscutum sp., Cretarhabdus crenulatus, $C$. loriei, Cribrosphaera sp. (two-piece diagonal centralarea crossbar), Cyclagelosphaera margerelii, Lithastrinus floralis, Parhabdolithus angustus, $P$. asper, $P$. embergeri, Prediscosphaera cretacea, Vagalapilla matalosa, Watznaueria barnesae, W. britannica, W. ovata, Zygodiscus bicrescenticus, Zygodiscus sp. The assemblage of Sample 257-7-2, $81-82 \mathrm{~cm}(201 \mathrm{~m})$ is more etched, but the species composition is similar; $C$. margerelii and $P$. asper are absent.

\section{SITE 258}

\section{(lat $33^{\circ} 47.69^{\prime} \mathrm{S}$, long $112^{\circ} 28.42^{\prime} \mathrm{E}$, depth $2793 \mathrm{~m}$ )}

Coccoliths of Early and Late Cretaceous age occur in Cores 5 to $22(124-445 \mathrm{~m})$ from Site 258 on the Naturaliste Plateau. The uppermost assemblages of Santonian age in Cores 5 to 7 (124-162 m) are well preserved and differ from each other only in the relative abundance of species. Chiastozygus disgregatus, a species common in the lower Santonian of Texas (Bukry, 1969), is most common here in Samples 258A-9-3, $28 \mathrm{~cm}(116 \mathrm{~m})$ and 258-6-4, 93-94 cm (147 m). A typical assemblage of the Gartnerago obliquum Zone at this site from Sample 258-7-2,

\begin{tabular}{l|c|c|c}
\hline $\begin{array}{c}\text { Sample } \\
\text { (Interval in cm) }\end{array}$ & $\begin{array}{c}\text { Quantity } \\
\text { and } \\
\text { Preservation }\end{array}$ & Zone & Stage \\
\hline $7-2,81-82$ & $\mathrm{Am}$ & & \\
$7-5,80-81$ & $\mathrm{Ag}$ & Prediscosphaera & Albian \\
$8-1,86-87$ & $\mathrm{Ag}$ & cretacea & \\
$8-2,3-4$ & $\mathrm{Ag}$ & & \\
$9-1,145-146$ & - & & $?$ \\
$9-2,146-147$ & - & $?$ & \\
$9-3,67-68$ & - & & \\
$10-1,8-9$ & - & & \\
\hline
\end{tabular}

Figure 6. Quantity, preservation, zone, and stage designations of samples from Site 257 based on coccoliths. See Figure 4 for key to abbreviations.
$80-81 \mathrm{~cm}(154 \mathrm{~m})$ contains Biscutum sp., Broinsonia brevieri, Cretarhabdus crenulatus, Effellithus augustus, E. turriseiffeli, Gartnerago obliquum, Kamptnerius magnificus, Lithastrinus floralis, Micula decussata, Prediscosphaera cretacea, Stephanolithion laffitei, Watznaueria barnesae, Zygodiscus deflandrei, and Zygodiscus spp.

A single sample of the Coniacian or Santonian Marthasterites furcatus Zone occurs at the top of Core 9 in Sample 258-9-1,145-146 cm (182 m). The assemblage is much more diverse than that recovered at the deepwater Site 250. Species present include Biscutum sp., Broinsonia bevieri, Cretarhabdus crenulatus, Eiffellithus augustus, E. turriseiffeli, Gartnerago obliquum, Lithastrinus floralis, Marthasterites furcatus, Micula decussata, Parhabdolithus angustus, Prediscosphaera cretacea, Watznaueria barnesae, $W$. biporta, W. ovata, Zygodiscus deflandrei, and Zygodiscus spp.

The presence of Tetralithus pyramidus without Marthasterites furcatus in Cores 10 and 11 (200-225 m) suggests a Coniacian assignment. The relative ranges of key species in the Cenomanian to Campanian are still not established. For example, at some localities in France, $M$. furcatus appears before $T$. pyramidus (Manivit, 1971). The assemblage of Sample 258-11-2, $78-79 \mathrm{~cm}(217 \mathrm{~m})$ includes Cylindralithus coronatus, Eiffellithus augustus, E. turriseiffeli, Gartnerago costatum, G. obliquum, Lithastrinus floralis, Lithraphidites carniolensis, Prediscoaphaera cretacea, Tetralithus pyramidus, Watznaueria barnesae, $W$. coronata, $W$. ovata, Zygodiscus deflandrei, and Zygodiscus spp.

Samples from Cores 12 and $13(235-263 \mathrm{~m})$ contain poorly diagnostic assemblages. They are possibly of Turonian age based on rare specimens of Kamptnerius magnificus. Sample 258-12-5, 64-65 cm (242 m) contains Biscutum sp., Broinsonia bevieri, Eiffellithus turriseiffeli, Gartnerago costatum, G. obliquum, Kamptnerius magnificus, Lithastrinus floralis, L. grillii, Lithraphidites carniolensis, Manivitella permmatoidea, Podorhabdus dietzmannii, Prediscosphaera cretacea, Watznaueria barnesae, $W$. biporta, Zygodiscus bicrescenticus, $Z$. deflandrei, and Zygodiscus spp. No specimens of Cribrosphaera are present in this or higher samples, but a new species of Cribrosphaera is present in Core 14 and all deeper coccolith-bearing cores. Questionable Cribrosphaera ehrenbergii was noted only in Sample 258-16-2, $85 \mathrm{~cm}$ (302 m).

No specimens of Lithraphidites alatus or Eiffellithus augustus, which would suggest Cenomanian, were observed in Cores 14 to $18(263-273 \mathrm{~m})$. The initial appearance of Gartnerago obliquum also may suggest Cenomanian; it appears first in Sample 258-14-1, 139$140 \mathrm{~cm}(264 \mathrm{~m})$. On the basis ofthe co-occurrence of Eiffellithus turriseiffeli and Prediscosphaera cretacea through the interval of Cores 14 to 18, an Albian or Cenomanian age is indicated (Figure 7).

The oldest coccolith-bearing cores, 20 and 21 (377-415 $\mathrm{m})$, contain diverse moderately etched assemblages of the lower Albian Prediscosphaera cretacea Zone. Sample 258-20-1, 108-109 cm (377 m) contains Cretarhabdus crenulatus, C. loriei, Cribrosphaera sp. (two-piece diagonal central-area crossbar), Cyclagelosphaera 


\begin{tabular}{|c|c|c|c|}
\hline $\begin{array}{c}\text { Sample } \\
\text { (Interval in } \mathrm{cm} \text { ) }\end{array}$ & $\begin{array}{c}\text { Quantity } \\
\text { and } \\
\text { Preservation }\end{array}$ & Zone & Stage \\
\hline $5-1,75-76$ & Ag & \multirow{4}{*}{ Gartnerago obliquum } & \multirow{5}{*}{ Santonian } \\
\hline $5-3,81$ & $\mathrm{Ag}$ & & \\
\hline $9 A-3,28$ & $\mathrm{Ag}$ & & \\
\hline $\begin{array}{l}6-4,93-94 \\
7-2,80-81\end{array}$ & \multirow{2}{*}{$\begin{array}{l}\mathrm{Ag} \\
\mathrm{Ag}\end{array}$} & & \\
\hline $\begin{array}{l}7-2,80-81 \\
9-1,145-146\end{array}$ & & Marthasterites furcatus & \\
\hline $10-2,43-44$ & Am & \multirow[b]{2}{*}{ Tetralithus pyramidus } & \multirow{2}{*}{ Coniacian (?) } \\
\hline $11-2,78-79$ & $\mathrm{Am}$ & & \\
\hline $12-2,44-45$ & Am & & \multirow[b]{2}{*}{ Turonian (?) } \\
\hline $\begin{array}{l}12-5,64-65 \\
13-3,148-149\end{array}$ & $\begin{array}{l}\mathrm{Ag} \\
\mathrm{Cm}\end{array}$ & ? & \\
\hline $14-1,139-140$ & Am & \multirow{8}{*}{ Eiffellithus turriseiffeli } & \multirow{8}{*}{ Cenomanian } \\
\hline $15-2,138-139$ & $\mathrm{Am}$ & & \\
\hline $15-5,100-101$ & $\mathrm{Rp}$ & & \\
\hline $\begin{array}{l}16-2,85 \\
16-5,30-31\end{array}$ & $\begin{array}{l}\mathrm{Cm} \\
\mathrm{Cp}\end{array}$ & & \\
\hline $17-2,80-81$ & Rp & & \\
\hline $17-4,147-148$ & $\mathrm{Am}$ & & \\
\hline $18-2,80-81$ & $\mathrm{Cm}$ & & \\
\hline $18-4,144-145$ & Am & & \\
\hline $20-1,108-109$ & $\mathrm{Cm}$ & \multirow{3}{*}{ Prediscosphaera cretacea } & \multirow{3}{*}{ Albian } \\
\hline $21-1,80-81$ & $\mathrm{Cg}$ & & \\
\hline $21-3,100-101$ & $\mathrm{Cm}$ & & \\
\hline $\begin{array}{l}22-3,111-112 \\
23-2,121-122\end{array}$ & Rp & \multirow{4}{*}{ ? } & \multirow{4}{*}{$?$} \\
\hline $24-3,53-54$ & - & & \\
\hline $24-5,120-121$ & - & & \\
\hline $25-3,85-86$ & - & & \\
\hline
\end{tabular}

Figure 7. Quantity, preservation, zone, and stage designations of samples from Site 258 based on coccoliths. See Figure 4 for key to abbreviations.

margerelii, Lithastrinus floralis, Manivitella pemmatoidea, Parhabdolithus angustus, Podorhabdus dietzmannii, $P$. reinhardtii, Prediscosphaera cretacea, Stephanolithion laffitei, Vagalapilla matalosa, Watznaueria barnesae, $W$. sp. cf. W. britannica, and Zygodiscus spp. The lowest sample, 258-21-3, 100-101 cm $(410 \mathrm{~m})$, is more etched and less diverse. Species present include Biscutum sp., Cretarhabdus crenulatus, Cribrosphaera sp., Cyclagelosphaera margerelii, Lithastrinus floralis, Manivitella pemmatoidea, Parhabdolithus angustus, Podorhabdus dietzmannii, Prediscosphaera cretacea, Vagalapilla sp., Watznaueria barnesae, W. britannica, W. ovata, and Zygodiscus spp.

\section{REFERENCES}

Bukry, D., 1969. Upper Cretaceous coccoliths from Texas and Europe: Kansas Univ. Paleontol. Contr., Protista, v. 2. 1973, Coccolith stratigraphy, eastern equatorial Pacific, Leg 16 Deep Sea Drilling Project, In van Audel, T. H., Heath, G. R., et al., Initial Reports of the Deep Sea Drilling Project, Volume 16: Washington (U.S. Government Printing Office), p. 653.

, in press. Low-latitude coccolith biostratigraphic zonation, In Edgar, N. T., Saunders, J. B., et al., Initial Reports of the Deep Sea Drilling Project, Volume 15: Washington (U.S. Government Printing Office), p. 685703.

Bukry, D. and Foster, J. H., in press. Silicoflagellate zonation of Upper Cretaceous to lower Miocene deep-sea sediment: U.S. Geol. Survey J. Res., v. 2, no. 3.

Cepek, P. and Hay, W. W., 1969. Calcareous nannoplankton and biostratigraphic subdivision of the Upper Cretaceous: Gulf Coast Assoc. Geol. Soc. Trans., v. 19, p. 323.

Douglas, R. G. and Bukry, D., 1973. Sources of error in dating Mesozoic deep-sea sediment: Geol. Soc. Am. Prog. Abs., v. 5.

Harland, W. B., Smith, A. G., and Wilcock, B. (Eds.), 1964. The Phanerozoic time-scale: Geol. Soc. London Quart. J., v. 120.

Izett, G. A., Cobban, W. A., and Gill, J. R., 1971. The Pierre Shale near Kremmling, Colorado, and its correlation to the east and the west: U.S. Geol. Surv. Prof. Paper 684-A, p. 1.

Lambert, R. St. J., 1971. The pre-Pleistocene Phanerozoic time scale-a review: Geol. Soc. London Spec. Pub. 5, p. 9.

Manivit, H., 1971. Nannofossiles calcaires du Crétacé Français (Aptien-Maestrichtien): Fac. Sci. d'Orsay, Thèse Doctorate d'Etat.

Roth, P. H., 1973. Calcareous nannofossils-Leg 17, Deep Sea Drilling Project: In Winterer, E. L., Ewing, J. I., et al., Initial Reports of the Deep Sea Drilling Project, Volume 17: Washington (U.S. Government Printing Office), p. 695.

Stradner, H., 1964. New contributions to Mesozoic stratigraphy by means of nannofossils: World Petrol. Congr., 6th, Frankfurt am Main, Proc., sec. 1, p. 167.

Thierstein, H. R., 1971. Tentative Lower Cretaceous calcareous nannoplankton zonation: Ecolog. Geol. Helv., v. 64, p. 459.

van Andel, T. H. and Bukry, D., 1973. Basement ages and basement depths in the Eastern Equatorial Pacific from Deep Sea Drilling Project Legs 5, 8, 9, and 16: Geol. Soc. Am. Bull., v. 84, p. 2361. 